\title{
Reducing anti-nutritional factor and enhancing yield with advancing time of planting and zinc application in grasspea in Ethiopia
}

\author{
Ashutosh Sarker, ${ }^{a^{*} \odot \text { Asnake Fikre, }}{ }^{b}$ Ali M Abd El-Moneim, ${ }^{a}$ Hani Nakkoul ${ }^{a}$ \\ and Murari Singh ${ }^{a}$
}

\begin{abstract}
BACKGROUND: Grasspea (Lathyrus sativus L.) is an important pulse crop for food, feed and sustainable crop production systems in Ethiopia. Despite its advantages in nutrition and adaptability to harsh climate and low fertile soil, it contains a neurotoxin, $\beta$ - $N$-oxalyl- $\alpha, \beta$-diamiono propionic acid ( $\beta$-ODAP), which paralyses the lower limbs and is affected by genotypic and agronomic factors. To determine the effect of zinc application and planting date on yield and $\beta$-ODAP content of two genotypes, experiments were conducted in two regions of Ethiopia.

RESULTS: The main effects of variety, sowing date and zinc and their interactions were significant $(P<0.001)$ for $\beta$-ODAP and seed yield, which had a linear relationship with zinc. For the improved grasspea variety, an application of $20 \mathrm{~kg} \mathrm{ha}^{-1} \mathrm{zinc} \mathrm{showed}^{-1}$ a reduction of $\beta$-ODAP from $0.15 \%$ to $0.088 \%$ at Debre Zeit and $0.14 \%$ to $0.08 \%$ at Sheno and increased its yield from $841 \mathrm{~kg} \mathrm{ha}^{-1}$ to $2260 \mathrm{~kg} \mathrm{ha}^{-1}$ at Debre Zeit and from 715 to $1835 \mathrm{~kg} \mathrm{ha}^{-1}$ at Sheno. Early sowing showed a reduction in ODAP content in relation to the late sowing.
\end{abstract}

CONCLUSION: An application of Zn beyond even $20 \mathrm{~kg} \mathrm{ha}^{-1}$ with an early sowing is recommended for the improved variety.

(c) 2017 Society of Chemical Industry

Keywords: grasspea; $\beta$-ODAP; zinc application; planting date; Ethiopia

\section{INTRODUCTION}

Grasspea (Lathyrus sativus L.) is an important pulse crop for food, feed and sustainable crop production system. It is rich in protein and many essential micro-nutrients, contributes to nutrition sustainability of the poor in Bangladesh, India, Ethiopia, Nepal, Eritrea and parts of China, and forms a significant construct in diversifying the cropping systems. ${ }^{1,2}$ It is grown in about 1.1 million hectares globally of which about 0.16 million hectares is in Ethiopia. Its delicious and the soft fodder supplies quality roughage requirements for livestock; its straw is valuable in animal feed as well. ${ }^{3}$ Due to its ability to fix nitrogen, like other pulse crops, grasspea adds substantial quantities of nitrogen, carbon and organic matter deposition in soil; the succeeding crop needs less fertiliser input, thus reducing the cost of cultivation. It is a very hardy crop with respect to drought tolerance, fewer attacks by pests and diseases and can also thrive well under waterlogging conditions. When other crops fail due to drought and adverse environmental conditions, it serves as a human staple food in times of famine. Grasspea is known by various local names such as 'Khesari' in Bangladesh and eastern India and Nepal, 'Tiwara' and 'Latki' in central India, 'Guaya' in Ethiopia and Eritrea, 'San li dow' in China, and 'Mürdümük' in Turkey. Grasspea is generally consumed by tribal people and poor sections of the society which cannot afford other costly pulses and mineral products.

Despite its multifarious agronomic, ecological and nutritional advantages, grasspea has an ambivalent reputation. Its plant-parts contain a neurotoxin, $\beta$ - $N$-oxalyl $\alpha, \beta$-diamiono propionic acid $(\beta$-ODAP), which is a neurotoxic non-protein amino acid that causes irreversible paralytic symptoms of the lower limbs/legs if consumed in large quantities over a long period of time. Outbreaks of this disease were evident in Ethiopia, Bangladesh, India and China at various periods of food scarcity. ${ }^{2,4-9}$ Grasspea is mostly consumed through green parts, particularly tender twigs used as leafy vegetables, but its seed is the main component used for human food as well as various preparations. Its split cotyledons are used as 'Dal' in South Asia and eaten with rice/bread and as 'Oat' in Ethiopia. Its flour is also used for making various palatable snacks like 'Piaju' in Bangladesh and 'Pakoura' in India. Indian consumers found that 'Pakoura' made of a mix of chickpea and grasspea flour gives more palatability or enhanced taste. Based on a review of the effects of different processing methods on nutritional composition and anti-nutritional factors with a view to improve the nutritional quality and reducing the anti-nutritional factors of grasspea,

\footnotetext{
* Correspondence to: A Sarker, Regional Coordinator \& Food Legume Breeder, ICARDA South Asia \& China Regional Program, 2nd Floor, Office Block-C, NASC Complex, DPS Marg, New Delhi-110012, India. E-mail:a.sarker@cgiar.org

a International Center for Agricultural Research in the Dry Areas (ICARDA), Aleppo, Syria

b Debre Zeit Agricultural Research Center, Debre Zeit, Ethiopia
} 
the optimisation of processing conditions to minimise the nutrient loss has been recommended. ${ }^{10}$

Some researchers have reported an association between $\beta$-ODAP content and seed coat colour. Genotypes with white seed coat have low $\beta$-ODAP contents. Moreover, when the seeds are boiled, the effect of $\beta$-ODAP is reduced. But caution has been recommended for consuming seed and forage of grasspea, and grasspea products only in small quantities in order to avoid the neuro-lathyrism disorder. ${ }^{11-13} \beta$-ODAP concentration in grasspea seeds is reported to have high genotype $\times$ environment $(G \times E)$ interaction. To ensure safe consumption of grasspea with lower $\beta$-ODAP concentration in food products, there are various options such as genetic detoxification through breeding, agronomic manipulation and physico-chemical detoxification. Of these, we have undertaken agronomic means to lower $\beta$-ODAP concentration in this study. Among many environmental and edaphic factors, drought, salinity, and zinc concentration in soil have direct influence on seed $\beta$-ODAP concentration. For example, a crop grown under drought conditions and under zinc deficient soil will have more $\beta$-ODAP content in seeds., ${ }^{9,14-16}$ In an extensive evaluation of grasspea germplasm of different origins during 1989-1990 with a view to identify toxin-free lines, several lines had low $\beta$-ODAP content but no line was $\beta$-ODAP free. ${ }^{17}$ However, a number of cultivars with low toxin content compared to local landraces were found in Ethiopia. ${ }^{18}$ The effect of zinc and phosphorus application on $\beta$-ODAP and yield of grasspea were evaluated in northern Syria, ${ }^{15}$ while in another study, a number of improved lines were found to contain $<0.10 \% \beta$-ODAP and the factors such as zinc application, early sowing and seed soaking had a favourable effect on the toxin reduction. ${ }^{19}$

The International Center for Research in the Dry Areas (ICARDA) is working on grasspea to develop low $\beta$-ODAP varieties and production technologies which will ensure low $\beta$-ODAP synthesis in its seeds and to deliver these improved technologies to the national programmes of Ethiopia, among other grasspea growing countries. In this study, an experiment with an improved promising line and a local variety in two representative grasspea growing regions in Ethiopia, was conducted to evaluate (1) the effect of zinc application and planting date on yield and $\beta$-ODAP content of grasspea varieties and their interaction, and (2) modelling of $\beta$-ODAP content and yield in terms of zinc application to the soil to compare the above factors.

\section{MATERIAL AND METHODS}

Experiments were conducted for 2 years (2001/2002 and 2002/2003) at two locations, Debre Zeit and Sheno, where the soil was low in available zinc at $<0.4 \mathrm{mg} \mathrm{kg}^{-1}$ (Debre Zeit) and $0.3 \mathrm{mg}$ $\mathrm{kg}^{-1}$ (Sheno). Debre Zeit Agricultural Research station (latitude: $10^{\circ} 34^{\prime} 60 \mathrm{~N}$; longitude: $35^{\circ} 47^{\prime} 60 \mathrm{E}$, altitude: $2539 \mathrm{~m}$ asl) in central Ethiopia has a deep heavy, black clay (vertisol), with a long-term (1953-2003) average rainfall of $839 \mathrm{~mm}$ and temperature of $18^{\circ} \mathrm{C}$. Its agroecology is tepid to cool sub-moist with dry (October to May) and rainy (June to September) seasons. ${ }^{16}$ Sheno (latitude: $9^{\circ}$ $20^{\prime} \mathrm{N}$; longitude: $39^{\circ} 18^{\prime} \mathrm{E}$, altitude: $2800 \mathrm{~m}$ asl) has about $60 \%$ clay and an annual rainfall of about $900 \mathrm{~mm}$, with excess rain in July and August (http://www.fao.org/wairdocs/ilri/x5493e/x5493e0w .htm).

At each of these two locations, an split-plot experiment in randomised complete blocks with three replications was conducted, where the two sowing dates, 29 August and 12 September (during 2001 and 2002), were allotted to the main plots, and factorial combinations of two genotypes ILAT-LS-520 and the Debre Zeit local landrace of dark seed coat colour and the five levels of zinc doses $\left(0,5,10,15,20 \mathrm{~kg} \mathrm{ha}^{-1}\right)$ in the form of basic zinc sulfate $\left(\mathrm{ZnSO}_{4}\right)$ were applied to the sub-plots. The sub-plot size was $2 \mathrm{~m} \times 4 \mathrm{~m}$ and the spacing between main plots was $1.5 \mathrm{~m}$. The $\beta$-ODAP content was determined following the standard calorimetric method of $\mathrm{RaO}^{20}$ which was further modified by Briggs et $a .^{21}$ and seed yield was recorded on a per plot basis.

\section{Statistical analysis}

Analysis of variance (ANOVA) was carried out to assess the effect of sowing date (SD), genotypes (G) and the zinc applied, and their interactions, as well as interactions of these effects with location and year on $\beta$-ODAP content and seed yield. The location and year combination was partitioned as location and year within locations since the year-to-year climatic condition may not be assumed to be the same over each location. Furthermore, the location effects were assumed as fixed and year effects as random. ${ }^{22}$ The ANOVA structures of the standard split-plot design was considered for individual location and year combination, while a combined analysis was carried out over location and years. It was observed that the error variances for $\beta$-ODAP content were homogeneous over the year-location combinations, therefore pooled ANOVA with a common error variance was carried out. For seed yield, the error variances were heterogeneous, so weighted ANOVA was carried out on the combined data to examine significance of main effects and interactions. Noticing the fact that most of the interactions with year were not significant but with locations were significant $(P<0.001)$, we carried out separate unweighted ANOVA for the split-plot design data combined over the years for each location, and estimated means with standard errors for comparisons. Furthermore, the variation due to zinc was partitioned into polynomial components to guide on $\beta$-ODAP content and zinc dose relationship. The mean response on $\beta$-ODAP content and yield were modelled using linear functions of applied zinc dose for each combination of genotype, planting time and locations. All the computations were carried out using GenStat statistical software (VSN International, 2015). ${ }^{23}$

\section{RESULTS}

Statistical analysis of $\beta$-ODAP content and seed yield of grasspea was carried out to assess the main effects and interactions of zinc, genotype and sowing date at the two locations over the 2 years. For the $\beta$-ODAP content, Table 1 shows that the main effects of the factors genotype, sowing date and zinc and their interactions were significant $(P<0.001)$. Interactions of these factors were significant except for the three-factor location $\times$ sowing date $\times$ genotype interaction. Among the interactions involving years within locations, only the year $\times$ genotype interaction was significant. On the seed yield as well, the various main effects and interactions of the experimental factors and locations listed above were significant. In addition, the three-factor interactions between sowing date, zinc and year within locations were also significant $(P<0.05)$. Further, the partition of variation due to zinc levels into linear and quadratic components showed high accountability by the linear components in all the significant interactions. Quadratic components were significant in a few cases while deviations from the quadratic model were generally insignificant. Since the variation due to zinc can be largely described by the linear component, therefore, this provided a basis for modelling the response to zinc as a linear function for the $\beta$-ODAP synthesis and yield. 


\begin{tabular}{|c|c|c|c|c|c|c|c|}
\hline \multirow[b]{2}{*}{ Source } & \multirow[b]{2}{*}{ DF } & \multicolumn{3}{|c|}{$\beta$-ODAP (\%) } & \multicolumn{3}{|c|}{ Yield } \\
\hline & & Zinc, overall & Zinc, linear & Zinc, quadratic & Zinc, overall & Zinc, linear & Zinc, quadratic \\
\hline Location & 1 & NV & - & - & NV & - & - \\
\hline Years (Yr) within (wtn) location & 3 & NV & - & - & NV & - & - \\
\hline Replications within Years within Location (Loc) & 8 & - & - & - & - & - & - \\
\hline Sowing Date (SD) & 1 & $<0.001$ & - & - & $<0.001$ & - & - \\
\hline Loc $\times S D$ & 1 & 0.128 & - & - & 0.663 & - & - \\
\hline $\mathrm{SD} \times \mathrm{Yr}$ within location & 2 & 0.664 & - & - & 0.012 & - & - \\
\hline \multirow[t]{2}{*}{ Residual } & 8 & - & - & - & - & - & - \\
\hline & & - & - & - & - & - & - \\
\hline Genotype (G) & 1 & $<0.001$ & - & - & $<0.001$ & - & - \\
\hline Zinc (Z) & 4 & $<0.001$ & $<0.001$ & 0.779 & $<0.001$ & $<0.001$ & 0.009 \\
\hline $\mathrm{G} \times \mathrm{Z}$ & 4 & $<0.001$ & $<0.001$ & 0.024 & $<0.001$ & $<0.001$ & 0.011 \\
\hline$S D \times G$ & 1 & $<0.001$ & $<0.001$ & - & $<0.001$ & - & - \\
\hline$S D \times Z$ & 4 & $<0.001$ & 0.002 & 0.007 & $<0.001$ & $<0.001$ & 0.069 \\
\hline$S D \times G \times Z$ & 4 & $<0.001$ & $<0.001$ & 0.447 & $<0.001$ & $<0.001$ & 0.016 \\
\hline $\mathrm{Loc} \times \mathrm{G}$ & 1 & $<0.001$ & - & - & $<0.001$ & - & - \\
\hline Loc $\times Z$ & 4 & $<0.001$ & $<0.001$ & 0.779 & $<0.001$ & $<0.001$ & $<0.001$ \\
\hline $\mathrm{Loc} \times \mathrm{G} \times \mathrm{Z}$ & 4 & $<0.001$ & $<0.001$ & $<0.001$ & 0.001 & 0.839 & $<0.001$ \\
\hline $\mathrm{Loc} \times \mathrm{SD} \times \mathrm{G}$ & 1 & 0.644 & - & - & 0.172 & - & - \\
\hline $\mathrm{Loc} \times \mathrm{SD} \times \mathrm{Z}$ & 4 & $<0.001$ & $<0.001$ & 0.057 & 0.020 & 0.007 & 0.060 \\
\hline $\mathrm{Loc} \times \mathrm{SD} \times \mathrm{G} \times \mathrm{Z}$ & 4 & $<0.001$ & 0.079 & $(<0.001)^{\dagger}$ & 0.004 & 0.007 & $(0.043)^{\dagger}$ \\
\hline Yr $\times G$ wtn Loc & 2 & $<0.001$ & - & - & $<0.001$ & - & - \\
\hline Yr $\times Z$ wtn Loc & 8 & 0.14 & 0.002 & 1.00 & 0.002 & $<0.001$ & 0.147 \\
\hline $\mathrm{Yr} \times \mathrm{G} \times \mathrm{Z}$ wtn Loc & 8 & 0.872 & 0.164 & $(1)^{\dagger}$ & 0.327 & 0.327 & $(0.379)^{\dagger}$ \\
\hline $\mathrm{Yr} \times \mathrm{SD} \times \mathrm{V}$ wtn Loc & 2 & 0.673 & - & - & 0.292 & - & NS \\
\hline $\mathrm{Yr} \times \mathrm{SD} \times \mathrm{Z}$ wtn Loc & 8 & 1 & 0.97 & $(1)^{\dagger}$ & 0.816 & 0.998 & $(0.618)^{\dagger}$ \\
\hline $\mathrm{Yr} \times \mathrm{SD} \times \mathrm{G} \times \mathrm{Z}$ wtn Loc & 8 & 1 & $(1)^{\dagger}$ & - & 0.653 & - & - \\
\hline
\end{tabular}

$\beta$-ODAP (\%) for the improved variety was much lower than that for the local variety at any applied dose of zinc (Table 2). With application of $20 \mathrm{~kg} \mathrm{ha}^{-1}$ zinc on the improved variety, $\beta$-ODAP (\%) reduced from $0.15 \%$ to $0.088 \%$ at Debre Zeit and $0.14 \%$ to $0.08 \%$ at Sheno. The reduction for the local variety was from $0.58 \%$ to $0.33 \%$ at Debre Zeit and $0.43 \%$ to $0.27 \%$ at Sheno. Early sowing resulted in lower $\beta$-ODAP irrespective of genotype and location. $\beta$-ODAP content was found to reduce with zinc level for each combination of genotype, time of planting and location. Similar trend in decline of $\beta$-ODAP with zinc level was also found while working with a set of nine grasspea genotypes. ${ }^{15}$

Yield of the improved variety was much higher than that of the local variety at any applied dose of zinc (Table 3). With application of $20 \mathrm{~kg} \mathrm{ha}^{-1}$ zinc on the improved variety, yield increased from 841 to $2260 \mathrm{~kg} \mathrm{ha}^{-1}$ at Debre Zeit and from 715 to $1835 \mathrm{~kg} \mathrm{ha}^{-1}$ Sheno. The similar increase for the local variety was from 833 to $1533 \mathrm{~kg}$ $\mathrm{ha}^{-1}$ at Debre Zeit and 582 to $968 \mathrm{~kg} \mathrm{ha}^{-1}$ at Sheno. Early planting is advantageous for grain yield in each combination of genotype, zinc level and location. It was statistically significant $(P<0.05)$ for improved genotypes at all the combinations of zinc levels and location except at Debre Zeit when no zinc was applied, while for the local landrace increase in yield due to early planting was not statistically significant except when $10 \mathrm{~kg} \mathrm{ha}^{-1}$ zinc was applied at Debre Zeit and $15 \mathrm{~kg} \mathrm{ha}^{-1}$ at Sheno. The improved genotype responds significantly to the time of planting in reducing the $\beta$-ODAP content and increasing the yield.
Following the strong significance of linear components (Table 4), the regression line in zinc doses was fitted for each combination of location, sowing date and variety, and for the varieties overall and the relationships are shown in Fig. 1. The linear fit for these combinations showed percentage variance accounted for in the range $69-99 \%$ for $\beta$-ODAP and $89-98 \%$ for the yield and the slopes were statistically significant $(P<0.05)$. The effect of zinc in reducing the $\beta$-ODAP is shown by the negative slope in each case. The reliability of extrapolation of doses above $20 \mathrm{~kg} \mathrm{ha}^{-1}$ can always be questioned. Further experimentation with higher doses is needed. However, since $20 \mathrm{~kg} \mathrm{ha}^{-1}$ zinc is affordable to poor and marginal farmers and since the relationships of the $\beta$-ODAP content and yields are linear, the maximum affordable level is recommended.

\section{DISCUSSION}

This study showed variation in the $\beta$-ODAP due to variety, location and sowing date. Across the two locations, the mean content varied in the range $0.14-0.15 \%$ for the improved variety while $0.43-0.58 \%$ for the local variety. These values are in the range 0.20 to $0.45 \%$ reported for Debre Zeit, $2006 / 2007 .{ }^{18,24}$ The improved variety in this study showed a slightly lower level of $\beta$-ODAP when no zinc was applied in comparison with other studies.

In the field trial conducted at Tel Hadya, northern Syria, to examine the effect and interactions of zinc, phosphorus and 
Table 2. Mean $\beta$-ODAP \% response of zinc application on variety and sowing date at two locations in Ethiopia (combined over 2 years, 2002 and 2003)

\begin{tabular}{|c|c|c|c|c|c|c|c|}
\hline \multirow[b]{2}{*}{ Location } & \multirow[b]{2}{*}{ Genotype } & \multirow[b]{2}{*}{ SD } & \multicolumn{5}{|c|}{$\operatorname{Zinc}\left(\mathrm{kg} \mathrm{ha}^{-1}\right)$} \\
\hline & & & 0 & 5 & 10 & 15 & 20 \\
\hline \multirow[t]{7}{*}{ Debre-Zeit } & \multirow[t]{3}{*}{ G1 local } & D1 & 0.522 & 0.480 & 0.431 & 0.361 & 0.298 \\
\hline & & D2 & 0.644 & 0.585 & 0.466 & 0.431 & 0.371 \\
\hline & & Mean & 0.583 & 0.532 & 0.448 & 0.396 & 0.334 \\
\hline & \multirow[t]{3}{*}{ G2 improved } & D1 & 0.137 & 0.109 & 0.116 & 0.084 & 0.077 \\
\hline & & D2 & 0.168 & 0.158 & 0.137 & 0.130 & 0.100 \\
\hline & & Mean & 0.152 & 0.133 & 0.126 & 0.107 & 0.088 \\
\hline & \multicolumn{2}{|l|}{ Mean } & 0.368 & 0.333 & 0.287 & 0.251 & 0.211 \\
\hline \multirow[t]{7}{*}{ Sheno } & \multirow[t]{3}{*}{ G1 } & D1 & 0.401 & 0.344 & 0.319 & 0.287 & 0.229 \\
\hline & & D2 & 0.456 & 0.434 & 0.398 & 0.340 & 0.297 \\
\hline & & Mean & 0.428 & 0.389 & 0.358 & 0.314 & 0.267 \\
\hline & \multirow[t]{3}{*}{$\mathrm{G} 2$} & D1 & 0.125 & 0.111 & 0.090 & 0.079 & 0.061 \\
\hline & & D2 & 0.158 & 0.122 & 0.104 & 0.104 & 0.100 \\
\hline & & Mean & 0.142 & 0.116 & 0.097 & 0.091 & 0.081 \\
\hline & \multicolumn{2}{|l|}{ Mean } & 0.285 & 0.253 & 0.228 & 0.202 & 0.172 \\
\hline \multicolumn{8}{|c|}{ Standard errors of means in the various factor combinations } \\
\hline & $\mathrm{Z} \times \mathrm{SD} \times \mathrm{G}$ & $\mathrm{Z} \times \mathrm{SD}$ & $\mathrm{Z} \times \mathrm{G}$ & $\mathrm{SD} \times \mathrm{G}$ & G \\
\hline \multicolumn{3}{|l|}{ Debre-Zeit } & $0.0054(0.0052)$ & $0.0040(0.0037)$ & 0.0037 & $0.0028(0.0023)$ & 0.0017 \\
\hline \multicolumn{3}{|l|}{ Sheno } & $0.0056(0.0041)$ & $0.0048(0.0029)$ & 0.0029 & $0.0042(0.0018)$ & 0.0013 \\
\hline
\end{tabular}

Table 3. Mean yield response $\left(\mathrm{kg} \mathrm{ha}^{-1}\right)$ of zinc application on variety and sowing date at two locations in Ethiopia (combined over the 2 years)

\begin{tabular}{|c|c|c|c|c|c|c|c|}
\hline \multirow[b]{2}{*}{ Location } & \multirow[b]{2}{*}{ Genotype } & \multirow[b]{2}{*}{ SD } & \multicolumn{5}{|c|}{ Zinc $\left(\mathrm{kg} \mathrm{ha}^{-1}\right)$} \\
\hline & & & 0 & 5 & 10 & 15 & 20 \\
\hline \multirow[t]{7}{*}{ Debre-Zeit } & \multirow[t]{3}{*}{ G1 } & D1 & 896 & 1085 & 1306 & 1328 & 1477 \\
\hline & & $\mathrm{D} 2$ & 770 & 951 & 1090 & 1221 & 1588 \\
\hline & & Mean & 833 & 1018 & 1198 & 1274 & 1532 \\
\hline & \multirow[t]{3}{*}{ G2 } & D1 & 925 & 1352 & 1585 & 2218 & 2538 \\
\hline & & D2 & 758 & 968 & 1173 & 1497 & 1983 \\
\hline & & Mean & 841 & 1160 & 1379 & 1858 & 2260 \\
\hline & \multicolumn{2}{|l|}{ Mean } & 837 & 1089 & 1289 & 1566 & 1896 \\
\hline \multirow[t]{7}{*}{ Sheno } & \multirow[t]{3}{*}{ G1 } & D1 & 615 & 670 & 833 & 1006 & 1143 \\
\hline & & D2 & 548 & 614 & 744 & 776 & 793 \\
\hline & & Mean & 582 & 642 & 789 & 891 & 968 \\
\hline & \multirow[t]{3}{*}{ G2 } & D1 & 787 & 1283 & 1782 & 2037 & 2083 \\
\hline & & D2 & 644 & 982 & 1203 & 1400 & 1587 \\
\hline & & Mean & 715 & 1133 & 1493 & 1718 & 1835 \\
\hline & \multicolumn{2}{|c|}{ Mean } & 648 & 887 & 1141 & 1305 & 1401 \\
\hline \multicolumn{8}{|c|}{ Standard errors of means in the various factor combinations } \\
\hline & $\mathrm{Z} \times \mathrm{SD} \times \mathrm{G}$ & $Z \times S D$ & $Z \times G$ & $S D \times G$ & $G$ \\
\hline \multicolumn{3}{|l|}{ Debre-Zeit } & $59(61)$ & $40(43)$ & 43 & $21(28)$ & 19 \\
\hline \multicolumn{3}{|l|}{ Sheno } & $44(42)$ & $32(30)$ & 30 & $22(19)$ & 13 \\
\hline \multicolumn{8}{|c|}{$\begin{array}{l}\text { Genotypes: G1 = Debre-Zeit local variety; G2 = ILAT-LS-B10-520; } \\
\text { Sowing dates D1 = Sowing date } 1 \text { (29 August } 2001 \text { and 2002), D2 = Sowing date } 2 \text { (12 September } 2001 \text { and 2002), both locations }\end{array}$} \\
\hline
\end{tabular}

grasspea genotypes on $\beta$-ODAP and yield, ${ }^{15}$ estimates were substantially higher in comparison with those found in this study. Based on the nine genotypes, $\beta$-ODAP ranged from $0.25 \%$ to $0.57 \%$ in the absence of zinc and from $0.21 \%$ to $0.49 \%$ in the presence of $20 \mathrm{~kg} \mathrm{ha}^{-1} \mathrm{Zn},{ }^{15}$ while in this study (Table 2) it ranged from $0.14 \%$ to $0.58 \%$ and $0.08 \%$ to $0.33 \%$, respectively, in the absence and presence of the above levels of zinc application. While application of zinc showed a significant reduction in $\beta$-ODAP in Ethiopian conditions, the reduction was not that substantial at Tel Hadya. 
Table 4. Estimated linear equations in zinc for $\beta$-ODAP $\%$ and yield for variety, sowing date and combinations with location

\begin{tabular}{|c|c|c|c|c|c|c|c|c|}
\hline \multirow[b]{2}{*}{ Location } & \multirow[b]{2}{*}{ Sowing date } & \multirow[b]{2}{*}{ Genotype } & \multicolumn{3}{|c|}{$\beta$-ODAP $\%$} & \multicolumn{3}{|c|}{ Yield $\left(\mathrm{kg} \mathrm{ha}^{-1}\right)$} \\
\hline & & & Intercept & Slope & Adj. $R^{2} \%$ & Intercept & Slope & Adj. $R^{2} \%$ \\
\hline \multirow[t]{4}{*}{ Debre Zeit } & \multirow[t]{2}{*}{29 August } & Debre Zeit Local & 0.5313 & -0.01134 & 98.7 & 937.3 & 28.09 & 92.9 \\
\hline & & ILAT-LS-520 & 0.133 & -0.00287 & 84.1 & 904.9 & 81.85 & 97.8 \\
\hline & \multirow[t]{2}{*}{12 September } & Debre Zeit Local & 0.6391 & -0.014 & 96.0 & 742.7 & 38.13 & 93.7 \\
\hline & & ILAT-LS-520 & 0.1712 & -0.00329 & 94.7 & 679.7 & 59.61 & 94.9 \\
\hline \multirow[t]{4}{*}{ Sheno } & \multirow[t]{2}{*}{29 August } & Debre Zeit Local & 0.3963 & -0.00803 & 97.3 & 575.2 & 27.82 & 97.1 \\
\hline & & ILAT-LS-520 & 0.1254 & -0.00323 & 99.0 & 925 & 66.93 & 89.2 \\
\hline & \multirow[t]{2}{*}{12 September } & Debre Zeit Local & 0.4666 & -0.00817 & 96.8 & 565 & 13.01 & 87.9 \\
\hline & & ILAT-LS-520 & 0.1441 & -0.00265 & 68.8 & 702.2 & 46.09 & 97.8 \\
\hline \multirow{2}{*}{\multicolumn{2}{|c|}{ Over both locations and sowing dates }} & Debre Zeit Local & 0.5083 & -0.01038 & 99.8 & 705.1 & 26.76 & 99.1 \\
\hline & & ILAT-LS-520 & 0.1434 & -0.00301 & 98.2 & 802.9 & 63.62 & 99.6 \\
\hline
\end{tabular}
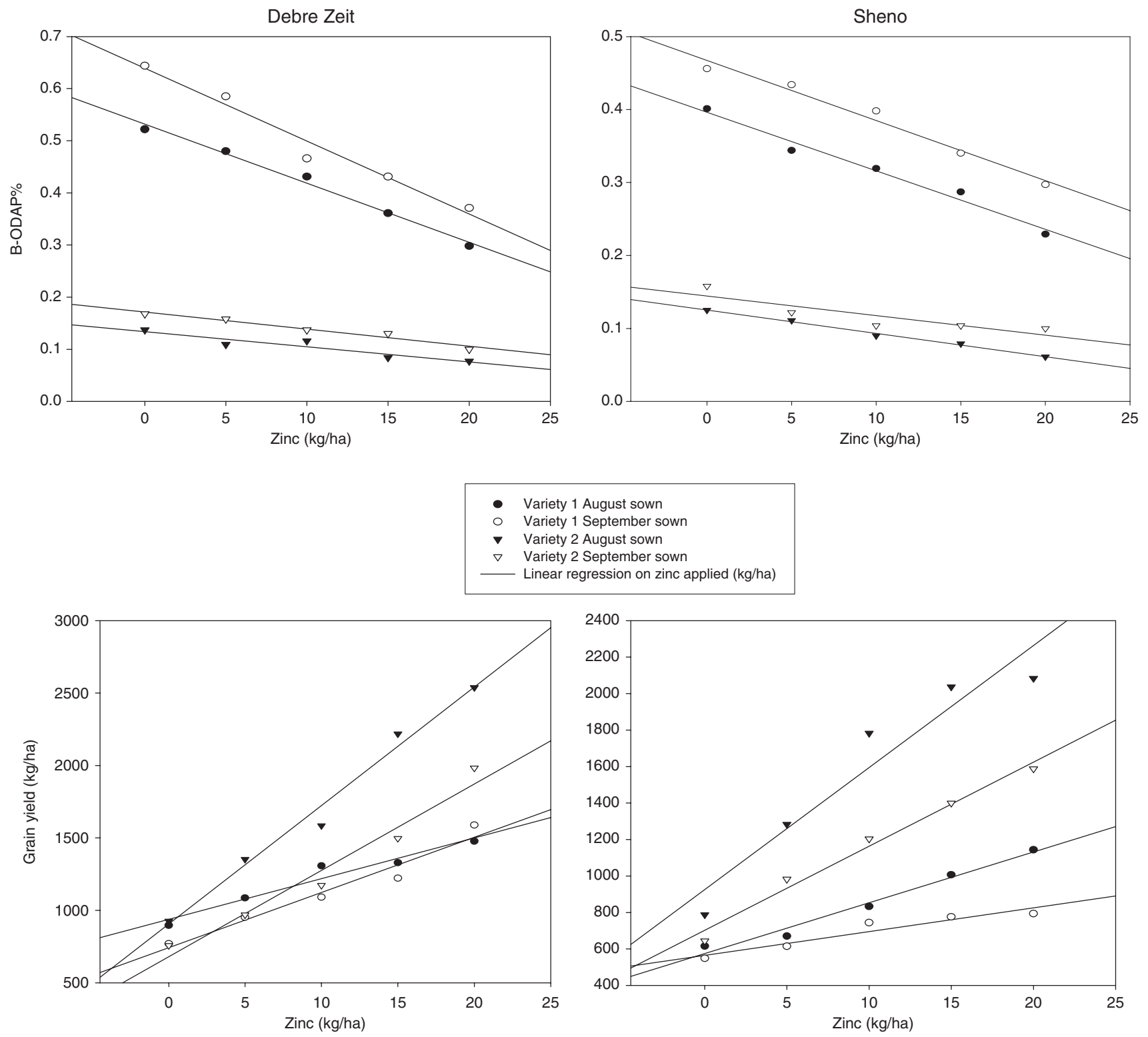

Figure 1. $\beta$-ODAP (\%) and grain yield $\left(\mathrm{kg} \mathrm{ha}^{-1}\right)$ response to application of zinc for two varieties sown in August and September 2001/2002 and 2002/2003 at two locations - Debre Zeit and Sheno - in Ethiopia. 
The study conducted at Debre Zeit in 2001/02-2002/03 showed difference in the estimates for the local and the improved line, over the 2 years: $0.28-0.34 \%$ for the local and $0.16-0.30 \%$ for the improved variety, in which case the two varieties were sown over two different sets of dates, therefore, the variety comparison is confounded with the set of dates. ${ }^{16}$ As a further exploration to estimating the effect of zinc on the toxicity and yield of grasspea, ${ }^{15}$ this study modelled their relationships with the zinc which guided on the amount of zinc that can be applied to contain the toxicity and increase the yield for specified target levels.

\section{CONCLUSION}

With the data obtained from the experimental conducted at two representative locations for Ethiopian conditions, this study has summarised the effects and interactions of grasspea variety, sowing date and zinc on the anti-nutrition content of $\beta$-ODAP and grain yield. It also modelled $\beta$-ODAP and grain relationships with zinc amount. The above factors showed significant main effects and two factor interactions. An early sowing favoured the response on $\beta$-ODAP and yield. The linear response relationship with zinc was found to increase for yield and decrease for $\beta$-ODAP, which can help determine the zinc dose for a target levels of the $\beta$-ODAP and or the yield.

\section{ACKNOWLEDGEMENTS}

The authors acknowledge the contributions of the late Dr Gelutu Bejiga at various stages of the research work reported in this study and are grateful to the reviewers for their constructive comments and suggestions which have significantly enriched the presentation.

\section{REFERENCES}

1 Papademetriou MK and Dent FJ (eds), Crop Diversification in the Asia-Pacific Region. FAO Regional Office for Asia and the Pacific, Bangkok (2001).

2 Hillocks RJ and Maruthi MN, Grass pea (Lathyrus sativus): Is there a case for further crop improvement? Euphytica 186:647-654 (2012).

3 Sayar MS and Han Y, Determination of seed yield and yield components of grasspea (Lathyrus sativus L.) lines and evaluations using GGE biplot analysis method. Tarım Bilimleri Dergisi - J Agric Sci 21:78-92 (2015).

4 Haimanat RT, Kidane YK, Wahib E, Kalissa A, Alemu T, Zein ZA et al., Lathyrism in rural north western Ethiopia: a highly prevalent neurotxic disorder. Int J Epidemiol 19:664-672 (1990).

5 Liu X and He F, Lathyrus sativus and lathyrism in China. Lathyrism Newsletter 2:2 (1990).

6 Haque A, Hossain M and Wouters G, Epidemiological and clinical study of lathyrism in Bangladesh: A preliminary report. Bangladesh J Neurosci 7:60-71 (1991).
7 Lambien F, Khan JK, Kuo HY, Campbell CC and Briggs IC, Toxins in seedlings of some varieties of grasspea (Lathyrus sativus). Nat Toxin 1:246-249 (1993).

8 Lambien F, Haque R, Khan JK, Kebede $\mathrm{N}$ and Kony H, From soil to grain: zinc deficiency increases the neurotoxicity of Lathyrus sativus and may effect the susceptibility for the motor zinc and neurotoxin toxicity neurone disease neurolathyrism. Toxicon 32:461-466 (1994).

9 Hanbury CD, Siddique KHM, Cawley NW and Cocks PS, Genotype-environment interaction for seed yield and ODAP concentration of Lathyrus sativus L. and L. cicera L. in Mediterranean type environments. Euphytica 110:45-60 (1999).

10 Demelash $\mathrm{H}$, Solomon A and Teka TA, Effects of processing on nutritional composition and anti-nutritional factors of grass pea (Lathyrus sativus L): A review. Food Sci Quality Manag 36:61 - 70 (2015).

11 Chowdhury SD, Lathyrism in poultry. World's Poultry Sci 44:7-16 (1988).

12 Gul I, Sumerli M and Yılmaz Y, Determination of yield and yield components of some grasspea (Lathyrus sativus L.) lines under Diyarbakır conditions. Tarım Bilimleri Dergisi - J Agric Sci 10:416-421 (2004).

13 Sayar MS, Han Y, Seydosoglu S and Basbag M, Determination of forage yield, its affecting components and relationships among traits of some grasspea (Lathyrus sativus L.) lines in Diyarbakır ecological conditions, in Proceedings of the 10th National Field Crop Congress, 10-13 September 2013, Konya, Turkey. Selçuk University, Konya, pp. 56-64 (2013).

14 Mannan A and Rahim A, Zinc in Nutrition. Bangladesh Agricultural Research Council, Dhaka (1988).

15 El-Moneim AMA, Nakkoul H, Masri S and Ryan J, Implications of zinc fertilization for ameliorating toxicity (neurotoxin) in grasspea (Lathyrus sativus). J Agric Sci Tech 12:69-78 (2010).

16 Bejiga G, Anbessa Y, El-Moneim AMA, Korbu L, Fikre A, Ryan J et al., Impact of grasspea genotypes and sowing dates on seed $\beta$-ODAP concentration and agronomic traits. Afric Crop Sci J 20:207-214 (2012).

17 El-Moneim AMA, van Dorrestein B, Baum M, Ryan J and Bejiga G, Role of ICARDA in improving the nutritional quality and yield potential of grasspea (Lathyrus sativus L.), for subsistence farmers in dry areas. Lathyrus News/ 2:55-58 (2001).

18 Denekew $Y$ and Tsega W, Evaluation of b-ODAP content in forage, grain and straw of Lathyrus sativus in North West Ethiopia. Livestock Res Rural Devel 21:Article \#212 (2009). Available: http://www.Irrd.org/ Irrd21/12/dene21212.htm [16 January 2017].

19 Kumar S, Bejiga G, Ahmed S, Nakkoul H and Sarker A, Genetic improvement of grass pea for low neurotoxin ( $\beta$-ODAP) content. Food Chem Toxicol 49:589-600 (2011).

20 Rao SLN, A sensitive and specific calorimetric method for the determination of $\alpha, \beta$-diamino-propionic acid and the Lathyrus sativus neurotoxin. Anal Biochem 96:386-395 (1978).

21 Briggs CJ, Parreno N and Campbell CG, Phytochemical assessment of $L$. sativus for the neurotoxin, B-N-oxolyl-L-B-diaminoproprionic acid. J Medical Plant Res 47:188-190 (1983).

22 Singh M, Grando S and Ceccarelli S, Measures of repeatability of genotype by location interactions using data from barley trials in northern Syria. Expl Agric 42:189-198 (2006).

23 VSN International, The Guide to the Genstat Command Language (Release 18), Part 2 Statistics. VSN International, Hemel Hempstead, UK (2015).

24 Urga K, Fufa H, Biratu E and Husain A, Evaluation of Lathyrus sativus cultivated in Ethiopia for proximate composition, minerals, $\beta$-ODAP and anti-nutritional components. Afr J Food Agric 5:1 - 15 (2005). 